\title{
Changes and modification of traditional ways of communication: an anthropological study on song and dance of 'urban oraon' at the district of north 24 parganas in West Bengal, India
}

\begin{abstract}
The study attempts to examine the changes and modifications of traditional or indigenous forms of communication in the tribal society. The urban cultural traits have entered their way of life every day. The main purpose of the study is to examine the process of how the 'Urban Oraon' people practice their own tradition after assimilating an urban cultural trait. Tribal dance and song are the traditional means of indigenous communication system. Traditionally, tribal people sent messages through song and dance and also even today they convey that but not same as traditional ways. Currently, they have made some changes. The present paper examined the channels through which the tribal people have changed their traditional communication system. This study was conducted on Oraon tribes who are living near the semi-urban towns in West Bengal
\end{abstract}

Keywords: oraon song and dance, changes and modification
Volume 3 Issue 6 - 2018

\section{Chinmay Biswas}

Sree Chaitanya College, India

Correspondence: Sree Chaitanya College, India, Email chinmavbiswas333@gmail.com

Received: October 24, 2018 | Published: November 07, 2018

\section{Introduction}

According to Dalton, SC Roy, Chakraborty M, Mukherjee $\mathrm{D},{ }^{1-3}$ and others the Oraons are an Agriculturalist Australoid tribe distributed over the state Bihar, Jharkhand, West Bengal, Madhya Pradesh and Orissa. They were probably migrated from peninsular India to their present home which is suggested by the language (Kurukh) they speak, a Dravidian language separated from that of the surrounding Munda language. SC Roy, Dalton and others wrote that Oraons connect themselves with Konkan. They are mostly distributed in Ranchi district. The skin colour is dark brown often approaching black. They are presently settled agriculturalists. Earlier days they were skilled hunters and played an important role in their socio-economic life. They have made plough for cultivation. The Oraons clans are totemic i.e. they are named after birds, fish, animals, vegetables, plants and minerals. According Dalton the concept of Bachelor hall is associated with Oraons culture. One of the most important bachelors home is named "Dhumkuria". He wrote that the bachelor hall of an Oraon village in which the boys and girls all slept every night. The Akhra, is a dancing arena which is situated in front of the 'Dhumkuria' Oraons of North 24 Parganas in West Bengal were migrated from Chotonagpur Plateau. They were come here as daily labour. Most probably they had come here for Railway construction and Jungle cutting under the Moneylenders or Land Owners. Afterwards they had not returned their original home, they lived here permanently. Oraons of these areas are most probably living since 100 years. During a long time living here the urban cultural traits have entered their socio-cultural life slowly. Urban cultural traits have affected their cultural life every day. The present paper navigates how Oraon of urban areas have sustained or maintained their own cultural identity?

\section{Review of literature}

The present study is intensively based of the concepts of Little \&
Great tradition was proposed by Robert Redfield ${ }^{4}$ in the studies of Mexican communities. The model is influenced by, Milton Singer ${ }^{5}$ and McKim Marriott; ${ }^{6,7}$ they were conducted some studies on social changes in India utilizing this conceptual frame work. The Great and Little tradition as proposed by Redfield ${ }^{4}$ usually mentioned in original religious epics. Their range is very wide, usually national in nature. These are related with elite, thinking, reflective few of urban class. Moreover, they usually organized and norms, rituals, etc. are largely clear-cut and unambiguous. The great traditions are transmitted from one generation to other through texts, sometimes these are referred to as "elite" tradition. Little tradition is mostly oral followed as more beliefs not necessarily based on rationally; these are mostly localized and related with rural unlettered, folk, tribal or peasantry. These are believed to be usually unorganized, haphazard and ambiguous, transmitted orally, through oral literature. The great tradition is cultivated in schools or temples, the little tradition works itself out and keeps itself going in the lives of the unlettered in their village communities ....The two traditions have long affected each other and continue to do so ....Great epics have arisen out of elements of traditional tale-telling by many people and epics have returned to the peasantry for modifications and incorporation in local cultures. ${ }^{8}$

Yogendra $^{9}$ explained that communication is considered as "Master Social Process" in the all discipline of Social science. It is very important for our Cognition realities. Yogendra ${ }^{9}$ explained that communication is considered as "Master Social Process" in the all discipline of Social science. It is very important for our Cognition realities. Communication represents a relationship not only individuals, but also between any kind of relationship. It is the web that binds society together. He further says 'Communication' mediates our access to social phenomena. People's construction of social reality through uses of variety of symbolic forms, such as the aural sounds, oral expressions, signs and languages. ${ }^{10}$ Wrote that the 
rituals and ritualistic activities express one of the most pervasive forms religious behaviors in tribal cultures. The tribal perform various rituals and observe festivities in response to seasonal changes and in the sense of new life keeping harmony with the nature as well as reflecting the existence of the bestowing super natural powers which are evolved to secure the good will of the benevolent sprits and to avert the displeasure of the malevolent ones. SC Dube ${ }^{11}$ suggested that traditions can be classified into following six fold.
a. The classical Tradition
b. The regional tradition
c. The local tradition
d. The western tradition
e. The emergent National Tradition; and
f. Sub cultural traditions of special groups.

The regional tradition means to the territorial spread of certain culture traits and complexes. It refers to spatial sharing of cultural elements give distinctiveness and identity to the regional culture. According Dalton and others said that the Oraons have adopted all Munda dances, and improved on them and also has lot of folk songs, dances; myth related tales as well as traditional musical instruments. Both sexes participated in dance which is performed any kind of socio-cultural activities and festival. They pass their time in music and dance. They sing folk songs in which their life style emerges. Their dances and songs are deeply rooted in their social and cultural life. Mandar, drums, Nagara and Dholak and flute are main musical instruments. Jhumur song of the Oraon reflects their philosophy of life.

\section{Objective of the study}

The study intends to find out the changes and modification of song and dance of "Urban Oraon".

\section{Method and technique}

Methodology may be used to refer to theoretical concerning the entire research proposal including the forms of thought of the research, aims and objectives of the research, application of the research methods "methodology" is also often used in a narrow sense to refer to the methods, techniques or tools for the collection and processing data. But in broader sense methods and techniques are one of the components of methodology. Finally, methodology may be called to designate all the components and procedure employed in the analysis data, however, collected to arrive at conclusion. Some of the following important field method and techniques have been applied in this study. To setting the data from my field I have taken the following techniques as used by all research scholars in social sciences including Anthropology. These are as follows:
a. Interview
b. Observation
c. Genealogy
d. Census survey
e. Photograph
f. Case study.

For collecting ethnographic data on song and dance, the interview case study and observation method were applied. For the traditional ethnographic account of the song and dance or secondary data has been collected from internet $\&$ books. For the research qualitative data is analyzed more.

\section{Discussion and results}

Two different localities have been selected for the study Sardar para (hamlet) of Dhalani. The village Dhalani is located under the Panchayet Koniara-1 in North 24 Parganas and other is Sardapara, ward No-1 in Gobardanga Municipality. In total 528 Oraon people are studied of which 272 are male (52\%) and 256 are female (48\%). About 121 families have been studied, out of which 80 small families, 29 medium families, 12 large. Out of 272 male, 161 are married and 108 unmarried and 3 widowers. In case female 153 are married, 83 unmarried, 19 widows and 1 divorce. According census 2011, Munda $(55,538)$, Oraon $(38,628) \&$ Bhumij $(34,387)$ of North 24 Parganas (Table 1) (Figure 1).

Table I Population distribution by age \& sex

\begin{tabular}{lllllll}
\hline Age group & Male & $\%$ & Female & $\%$ & GT & $\%$ \\
\hline 0 to 4 & 15 & 2.8 & 20 & 3.79 & 35 & 6.6 \\
5 to 9 & 18 & 3.4 & 14 & 2.66 & 32 & 6 \\
10 to 14 & 22 & 4.17 & 23 & 4.35 & 45 & 8.5 \\
$15-19$ & 21 & 3.9 & 35 & 6.6 & 56 & 10.6 \\
$20-24$ & 26 & 4.9 & 33 & 6.2 & 59 & 11.1 \\
$25-29$ & 31 & 5.87 & 23 & 4.3 & 54 & 10.2 \\
$30-34$ & 21 & 3.9 & 22 & 4.1 & 43 & 8 \\
$35-39$ & 29 & 5.4 & 21 & 3.9 & 50 & 9.3 \\
$40-44$ & 19 & 3.5 & 18 & 3.4 & 37 & 6.9 \\
$45-49$ & 22 & 4.1 & 18 & 3.4 & 40 & 7.5 \\
$50-54$ & 11 & 2 & 13 & 2.4 & 24 & 4.4 \\
$55-59$ & 12 & 2.26 & 2 & 0.3 & 14 & 2.5 \\
$60-64$ & 25 & 5.8 & 14 & 2.6 & 39 & 8.4 \\
Total & 272 & 52 & 256 & 48 & 528 & 100 \\
\hline
\end{tabular}

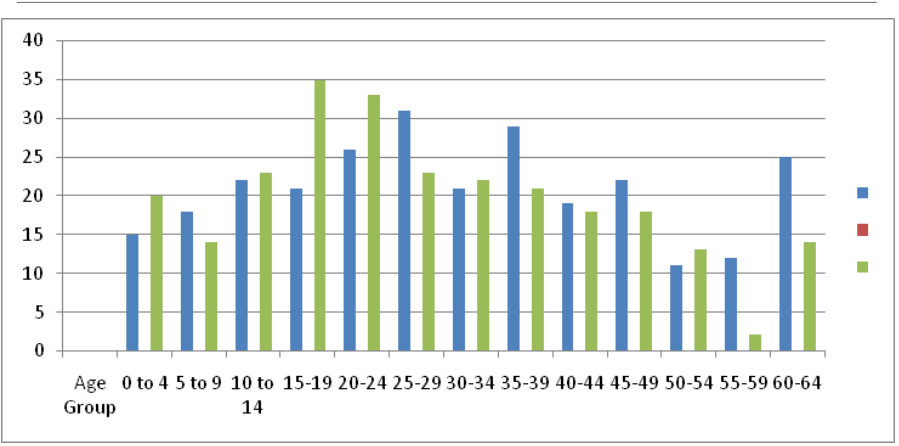

Figure I Graphical representation of Table I.

\section{Song}

The Oraons have songs appropriate to their different dances. The songs are distinguished from one another in rhythm and the manner of singing. All songs are primarily meant to be sung in accompaniment of dances and the names of songs are accordance with different kinds 
of dances. ${ }^{12}$ The present investigation has resulted that the ideal type or traditional type of song said by 'Patnaik' has already been changed. In Urban Oraon no traditional song is presently performed. All songs are translated from Sadri to Bengali. It is seen that their own rituals related songs are not translated and that are performed in Sadri language. It is note that both study area follows the same features to sing a song. While the song is sung in 'Parab' or festivals, they use microphone to convey the some messages to natives of other people. And they have invited others for listen their traditional song including Bengali words and before singing they express the inner meaning of the song. Their natives are Bengali speaking people for the reason they change their song in Bengali. Song's lyrics are made of both Bengali \& Sadri Language. In the present study it is recorded that some Bengali modern songs have entered in their way of life. Bengali modern songs have already been translated in Sadri language. Every day in evening they make kirtan in their house. Eventually no song is borrowed from their cradle house of Chotonagpur. Recently Urban Oroan write the Bengali script of mixed song i.e. Bengali and Sadri song. At the same time they have given training to their new generation. I have seen four categories song from my field.

a. Kali Puja related Sadri-Bengali Song

b. Bengali and Sadri mixed Jhumur Song

c. Translated Song (from Bengali to Sadri \& Sadri to Bengali).

\section{d. Kirtan Song}

Now the some song text or lyrics in Bengali \& Sadri are presented here.

Sadri -Bengali mixed Kalipuja related song. English translation: China rose has been collected for worshiping the goddess kali. For goddess the villagers will be engaged and form into a wreath. The Bengali text: Jaba ful ayyi jala tore jabai, Aaj Kali mai ki puja korbai....o..go.....malakhani...gatha bhai, Oi..dekhogo, puber bela kali mai, kakhan ful tolbai, puja korbai.

Bengali-Sadri Mixed Jhumur Song, Bengali song text (Lyrics): "Bane Bane aaney joyram karam, Bane Bane aaney joyram karam, Aajo se karam Raja ghare , tusar baney jay jay.....madal baja, Keo ba jtar k dhang....

Dhitang ..tang..tang..kesan sundar bajay k. English translation \& Meaning: Even today it is seen that the king name 'karam' has been travelling or rambling continuously in jungle. The Oraons are cordially invited their respected 'Karam' by playing madal (traditional musical instruments) with singing.

Kirtan Song-Bengali text (Lyrics): "Gor lagathi toke. Gore lagathi toke hum, Ghurathi firathi...humko..Gore lagathi toke Ghanashyam" English translation or meaning: Respect to Lord Krishna act of making obeisance by lying prostrate or bending touching feet (pronam). They have always been trying to give respect 'Krishna' through act of making obeisance by lying prostrate or bending touching feet.

\section{Dance}

\section{Dance dormitories}

It is a place where tribal people used to perform their own traditional dance in front of the dormitory. Gajrani ${ }^{13}$ described that "The dance of the Oroans in different regions is performed in front of the dormitories". However, in case of my present study the "Urban Oroan' (type-A \& type-B) has no dance dormitories. They perform dance in their own courtyard. So it may be said that 'the Urban Oraon use their courtyard as dance dormitories for performing the dance.

\section{Oraons jadura}

Dalton (1872) wrote in details on 'Oraon dance and Song', he said that "the Oraons have adopted all Munda dances, and improved on them. They have one called the 'Oraons Jadura, which is quite a refinement on the ordinary Jadura, most complicated in step and figure, but the movements in it are executed with wonderful precision by girls accustomed to dance it together". However in present study it has observed that 'Jadura dance' do not perform by the Urban Oraons. They have no knowledge about "Jadura".

\section{Major and minor dances}

Earlier studies focused that Oraons performed different types of major or minor dances like war dance (between two para), karma dance, khaddi or Sarhul dance, Phagu dance, Jadur dance, Chali dance, Wedding dance, Jhumur dance, Jarga and Martha dance (Prasad,1910). The Urban Oraons of both study areas are not habituated to perform major and minor dances. They have no details knowledge about Nalna dance.

i. No war dance has been seen in 'Urban Oraon' because they live semi-local towns in this district in different small pockets.

ii. 'Akhra' the place where Oraons were traditionally performed dance however the present study investigates no particular place is used by "Urban Oraon".

The following table shows the traditional dances which are even today found in Chotonagpur and the dances which are presently performed by the Urban Oraon as I have seen (Table 2). The above mentioned chart shows that Urban Oraon of the present study area are practiced three 'Minor dance' and two 'Major dance' by using Modern communication devices like microphone, sound system and modern Bengali Jhumur song. Sometimes they collected CD player from their cradle house 'Chotonagpur' region (Figure 2).

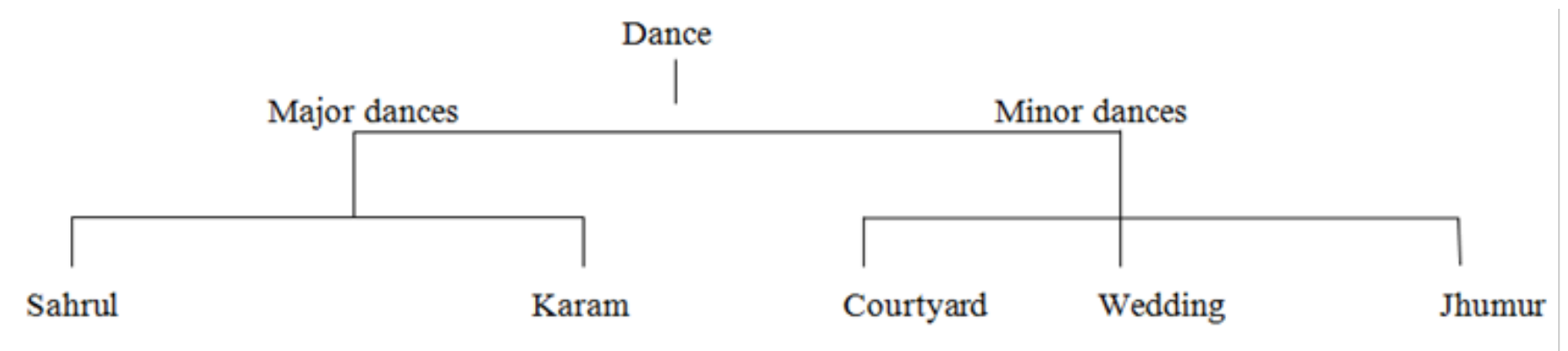

Figure 2 Classification of oraon dances. 
Table 2 Traditional dance \& Urban Oraon dances

\begin{tabular}{|c|c|c|}
\hline Traditional dances & & Urban oraon dances \\
\hline Major & Jadur dance & None found \\
\hline \multirow[t]{3}{*}{ Dances } & Khaddi or Sarhul & Only Sahrul is found \\
\hline & Kharia dance & None found \\
\hline & Karam & Found \\
\hline \multirow{2}{*}{ Minor Dances } & Wedding song & $\begin{array}{l}\text { They perform wedding dance but no approved song. It is seen that at the wedding of any person of the } \\
\text { study area Oraons are performed the dance with modern Bengali or Hindi song with use of Microphone } \\
\text { and sound system. Very little use of madal has been detected. }\end{array}$ \\
\hline & Jhumur song & \\
\hline
\end{tabular}

\section{Theoretical and social dancing}

Theoretical dancing is performed for the entertainment purpose of viewers. The theoretical dancing is formed and includes modern dance, musical commodity and tap dancing. Theoretical dancing takes a great personal satisfaction in creating something beautiful. However, their own enjoyment and need for self are important than their ability to interpret the dance effectively for audience. The present research enlightened that the modern technical mechanism has not been introduced to perform of "traditional and social dancing to some extent.

\section{Participating to local different cultural program organized by others}

The Urban Oraons have participated to cultural program of town area in Durgapja Mandap or stage. They perform different type of dance with song of Jhumur and in Sadri language. Before starting dancing they must interpret dance meaning to the audience so that the whole audience can be understood the actual meaning of the dance. It is also observed that they sometimes perform the dance in front of audience with Bengali songs.

The people of Gobardanga Municipality, Urban Oraon usually perform their dance in "Gobardanga Utsav" (annual cultural program organized by Gobardanga Municipality). In 'Maghe-Basi' festival they organize a cultural program and under the program list of that festival, a dance drama "Karam Katha Gaan-O-Nach ('Katha' the Bengali word means 'the description of karam;Katha=word) and Naach (Bengali word,that means dance) must be presented by Oraons performers. An educated person of the Oraon community (Gobardanga) writes the script on Karam katha. It has been observed that the lyric of the song has written in Bengali. Through these approaches the "Urban Oroan" has tried convey a message to larger people for their conventional reality.

\section{Conclusion}

Only one minor dance 'wedding dance' and a major dance 'Karam' are seen in the study. At present no traditional type of dances are practiced by them. No particular dance ground in the village has been found as told by SC Roy ${ }^{2}$ and Dixon. ${ }^{14}$ The traditional dance is performed on Durga Puja mondop in near town areas. In those places they modify and change their traditional dances by including with modern Hindi or Bengali songs due to the satisfaction of audience. They are very much concerned to the fact that the most viewers are non tribal people and Bengali speaking community. So they convey massages to audience by use local language as such Bengali. No traditional song type is seen in the present study. All songs are translated from Sadri to Bengali. When the song is singing in Parab or festivals, they use microphone to convey the some messages for natives of other people. And they have invited others to see their traditional song including some new Bengali words and before singing, they express the meaning of the song. Songs are made both Bengali and Sadri languages. In the study it has been observed that some Bengali modern songs translated in sadri and it is sung by them. Every day they play kirtan in their house. Thus way the 'Urban Oraon' people are changing their traditional communication system and to form a new cultural equilibrium. ${ }^{15-22}$

\section{Acknowledgements}

None.

\section{Availability of data and material}

As an author of this paper, I have not interested to share the data because the data which used in this article is completely primary or firsthand data; it was collected from the field area.

\section{Funding}

It is not applicable in this study.

\section{Conflict of interest}

Author declares that there is no conflict of interest.

\section{References}

1. Dalton ET. Descriptive Ethnology of Bengal. Calcutta: Office of the Superintendent of Govt; 1872.

2. Roy SC. The Oraons of Chotonagpur. Ranchi; 1915.

3. Mukherjee K, Bandapdhyay B, Banerjee A, et al. New Age Purohit Darpan. USA: Association of Grandparents of Indian Immigrants Nashville, First Edition; 2012

4. Redfield R. The Little Community. Chicago: The University of Chicago Press; 1955. 
5. Singer M. Traditional India: Structure and change. Philadelphia: American Folklore Society; 1958.

6. Marriot McK. Village India. Chicago: University Press; 1955.

7. Marriot McK. The Little Community. Chicago: Chicago University press; 1955.

8. Burke P. Popular Culture in Early modern Europe. Englad: Ashgate Publishing Limited; 2009.

9. Yogendra S. History of Science, Philosophy and Culture in Indian Civilization. New Delhi: IMH press; 2010. p. 3.

10. Debnath D. Ecology and Rituals in Tribal Areas. New Delhi: Sarup \& Sons; 2003.

11. Dube SC. India's Changing Villages. London: Routledge and Kegan Paul Ltd; 1958.

12. Patnaik N. Folklore of Tribal Communication. Mehera offset press; 2002.

13. Gajrani S. History of Religion \& Culture \& Media. New Delhi: Chowla offset press; 2004.

14. Dixon RB. The Oraons of Chotonagpur: Their History, Economic Life and Social Organisation by Sarat Chandra Roy, American Anthropologist. JSTOR. 1916;16(2):284-282.
15. Boas F. General Anthropology. USA: DC Heath Company; 1938.

16. Biswas C. Anthropology of Physics: Energy, Matter \& Culture, India. International Journal of Research Humanities and Social Studies. 2015;2(2):74-76.

17. Biswas C, Ray M. Lineage in Straight Line: An elementary study in Social Anthropology. Journal of South Asian Studies. 2012;2(3):2308-7846.

18. Marshal ML, Bruce RP. The Global Village: Transformations in World Life and Media in the 21st Century. UK: Oxford University Press; 1989.

19. Risley HH. Tribe and Caste of Bengal, Calcutta; 1991.

20. Tylor EB. Anthropology: An Introduction to Study of Man and Civilization. NewYork: DA Pleton and Company; 1890.

21. Vidyarthi LP, Raj Binay. The Tribal Culture of India. New Delhi: Concept Publishing Committee; 1996.

22. Xalxo P. Coplementary of Human Life and Other life forms in Nature. Rome: Gregorian University press; 2007. 